\title{
Comparison of moisture sorption isotherm models in freeze-dried pineapple pulp'
}

\author{
Humberto Vega-Mercado and Gustavo V. Barbosa-Cánovas"
}

\begin{abstract}
Moisture sorption isotherms of freeze-dried pineapple pulp were determined at $5,25,30,35$ and $55^{\circ} \mathrm{C}$. Water activity were controlled by using preselected saturated salt solutions in evacuated glass dessicators according to Wolf et al. (20), where microcrystalline cellulose is the reference material for the defermination of sorption isotherms. The data were correlated in terms of some empirical models involving two single parameters: models of Henderson, Oswin, Chung-Pfost, Halsey, Iglesias-Chirife, and Smith. Also, the data was correlated by the Guggenheim-Anderson-deBoer (G.A.B.) model involving three adjustable parameters. It was found that the models proposed by Henderson and Iglesias-Chirife were the most useful ones in predicting water activities at different levels and at different temperatures.
\end{abstract}

\section{RESUMEN}

Comparación de varios modelos de isotermas de sorbición en pulpa de piña liofilizada.

Se determinaron las isotermas de sorbición a $5,25,30,35$ y $55^{\circ} \mathrm{C}$ para pulpa de piña liofilizada. Se controló la actividad de agua mediante el uso de soluciones saturadas de sales en desecadores sellados al vacío siguiendo las recomendaciones publicadas por Wolf y cols. (20) y se utilizó celulosa microcristalina como material de referencia en la determinación de las isotermas. Los datos obtenidos se correlacionaron en términos de modelos empíricos que comprenden dos parámetros simples. Estos modelos son de Henderson, Oswin, Chung-Pfost, Halsey, Iglesias-Chirife, y Smith. Los datos también se ajustaron con el modelo propuesto por GuggenheimAnderson-deBoer (G.A.B.), el cual incluye tres parámetros. Se encontró que los modelos de Henderson a Iglesias-Chirife fueron los más útiles para predecir actividades de agua a diferentes niveles y a diferentes temperaturas.

\section{INTKODUCTION}

The relationship between total moisture content and the corresponding water activity over a range of values at constant temperature yields a moisture sorption isotherm. Sorption isotherms are used in food science

'Manuscript submitted to Editorial Board 20 March 1991. We express our gratitude to the Land Authority of Puerto Rico for supplying us with fresh pineapple pulp.

'Research Assistant, Laboratory of Food Technology. We thank Kevin M. Knight for graphical aid.

${ }^{3}$ Assistant Professor, Department of Biological Systems Engineering, Washington State University, Pullman, WA 99164-6120. 
and technology for a number of purposes. The main application is in drying, mixing, packaging and storing (11).

Most food products are complex in nature. Theoretical predictions of the isotherms are not trivial; therefore, experimental measurements are necessary, and existing or proposed models should be carefully tested.

Many food products, including pineapple pulp, that have not been very well utilized in the past are becoming key ingredients in new formulations; therefore, it is important to study those properties related to food stability, such as sorption isotherms.

The Langmuir equation (14) for the kinetic approach of adsorption isotherms has not been satisfactory for foods because 1) the heat of adsorption is not constant over the whole product surface; 2 ) there is interaction between adsorbed water molecules; and 3) adsorption is greater than that of only a monolayer $(7,14)$. Several models are found in the literature to represent sorption isotherms in foods. Some of them were developed for specific types of products and sets of conditions. Table 1 lists six reported two-parameter model sorption isotherms considered in this study. The Henderson model (8) has been reported as useful in predicting moisture content for different water activity levels. This model has been developed on the basis of a rigorous thermodynamic approach. Iglesias and Chirife (10) proposed an empirical model to predict sorption isotherms in fruits. This model works best in the water activity range of 0.10 to 0.80 . Chung and Pfost (5) developed a general sorption isotherm

TABLE 1. Equations reported as describing sorption isotherms. ${ }^{\prime}$

\begin{tabular}{ll}
\hline Henderson (8) & $X^{n}=\frac{-\ln \left(1-a_{w}\right)}{C_{1} \times T}$ \\
Oswin (17) & $X=C_{1}\left(\frac{a_{w}}{1-a_{w}}\right)^{n}$ \\
Chung-Pfost (5) & $X=\frac{-1}{C_{1}}$ In $\left.\quad \frac{-T \ln \left(a_{w}\right)}{C_{2}}\right)$ \\
Halsey (4) & $X^{n}=\frac{C_{1}}{\ln \left(a_{w}\right)}$ \\
Iglesias-Chirife (10) & $\ln \left(X+\sqrt{X^{2}+X ; n}=C_{1} \times a_{w}+C_{2}\right.$ \\
Smith (3) & $X=C_{1}+C_{2} \times \ln \left(1-a_{w}\right)$ \\
\hline
\end{tabular}

${ }^{2} \mathrm{n}, \mathrm{C}_{1}, \mathrm{C}_{2}$ are constant; $\mathrm{a}_{w}$ is water activity; $\mathrm{X}$ is moisture content; $\mathrm{T}$ is temperature; $\mathrm{X}_{\text {in }}$ is the water content at $0.5 \mathrm{a}_{w}$ level. 
J. Agric. Univ. P.R. vol. 77, NO. 3-4, JULY/OCTOBER, 1993115

considering a multilayer adsorption process. The Halsey equation was developed on the basis of condensation of multilayers, given that the potential energy of a molecule is proportional to the inverse nth power of its distance from the surface. Chixife and Iglesias (4) found that the Halsey model provides a good fit for 220 isotherms from 69 different food materials. The Smith equation has been useful in describing water sorption isotherms of various biopolymers and food products at $\mathrm{a}_{\mathrm{w}}$ of $0.3-0.5$ and higher. The Oswin model is a mathematical series expansion for $\mathrm{S}$ shaped curves, like many food sorption isotherms. From the six twoparameter models already mentioned, only two (Henderson's and ChungPfost's) include temperature as a variable.

Recently, it has been found that the three-parameter model proposed by Guggenheim-Anderson-deBoer (G.A.B.) is a useful one to predict sorption properties (11). This equation is an extension of the BrunauerEmmett-Teller (B.E.T.) equation, taking into consideration the modified properties of the sorbed water in the multilayer region (12). The G.A.B. model is useful to predict data up to about water activity levels of 0.9 , and it gives a better fit than the B.E.T. equation over a wide range of moisture contents. The G.A.B. equation has the following expressions:

$$
\begin{gathered}
\frac{\mathrm{W}}{\mathrm{W}_{\mathrm{m}}}=\frac{\mathrm{C} \mathrm{Ka}_{\mathrm{w}}}{\left(1-\mathrm{Ka}_{\mathrm{w}}\right)\left(1-\mathrm{Ka}_{\mathrm{w}}+\mathrm{C} \mathrm{Ka} \mathrm{w}_{\mathrm{w}}\right)} \\
\mathrm{a}_{\mathrm{w}}=\frac{2+\left(\mathrm{W}_{\mathrm{m}} / \mathrm{W}-1\right) \mathrm{C}-\left\{\left[2+\left(\mathrm{W}_{\mathrm{m}} / \mathrm{W}-1\right) \mathrm{C}\right]^{2}-4(1-\mathrm{C})\right\}^{0.5}}{2 \mathrm{~K}(1-\mathrm{c})}
\end{gathered}
$$

where $\mathrm{W}$ is water content (dry basis), $\mathrm{Wm}$ is the water content at "monolayer," C is the G.A.B. sorption constant related to monolayer properties, $\mathrm{K}$ is the G.A.B. sorption constant related to multilayer properties. The definition for the constants $\mathrm{C}$ and $\mathrm{K}$ are:

$$
\begin{aligned}
& C=\operatorname{cexp}\left(\frac{\mathrm{H}_{m}-\mathrm{H}_{n}}{R T}\right) \\
& \mathrm{K}=\mathrm{k} \exp \left(\frac{\mathrm{H}_{\mathrm{p}}-\mathrm{H}_{\mathrm{n}}}{\mathrm{RT}}\right)
\end{aligned}
$$

where $\mathrm{c}$ and $\mathrm{k}$ are entropic accommodation factors, $\mathrm{H}_{\mathrm{m}}$ is molar sorption enthalpy of the monolayer, $\mathrm{H}_{\mathrm{n}}$ is molar sorption enthalpy of the multilayer, $\mathrm{H}_{\mathrm{p}}$ is molar enthalpy of evaporation of liquid water, $\mathrm{R}$ is the gas constant, and $\mathrm{T}$ is absolute temperature. 
The G.A.B. equation can be transformed to:

$$
\frac{a_{w}}{w}=\alpha a_{w}^{2}+\beta a_{w}+\gamma
$$

where

$$
\begin{aligned}
& \alpha=\frac{\mathrm{K}}{\mathrm{W}_{\mathrm{m}}} \times\left[\frac{1}{\mathrm{C}}-1\right] \\
& \beta=\frac{1}{\mathrm{~W}_{\mathrm{m}}} \times\left[1-\frac{2}{\mathrm{C}}\right] \\
& \gamma=\frac{1}{\mathrm{~W}_{\mathrm{m}} \times \mathrm{c} \times \mathrm{k}}
\end{aligned}
$$

The quadratic expression [5] can be used to determine the $\alpha, \beta$, and $\gamma$ coefficients. Meanwhile, the $\mathrm{k}, \mathrm{c}$, and $\mathrm{W}_{\mathrm{m}}$ values can be evaluated from $\alpha, \beta$, and $\gamma$ values.

In general, a good sorption isotherm model is the one able to predict moisture content as a function of water activity in a wide range and for different temperatures. What is also an important consideration in selecting a model is the physical meaning of the parameters and variables involved.

Some models are good predictors of the sorption properties in a very specific range. Even though they offer some limitations, they could be easier to use or more accurate in their applicable range than those that are valid in a much wider water activity interval. It is also expected that the model constants will not be affected by temperature.

Even though there are no specific rules about the number of parameters in a model, in general, it is desirable to use the model with the least number of parameters because it will facilitate interpretations of results and curve fitting.

In general, when dealing with sorption measurements and sorption data, a reference system is recommended. In recent years, a group of European research laboratories developed such a system. It consists of a reference material, simple standard equipment with handling procedures, and recommendations for the evaluation of results. The reference material, microcrystalline cellulose Avicel PH $101^{4}$ (MCC) manufactured

\footnotetext{
"Trade names in this publication are used only to provide specific information. Mention of a trade name does not constitute a warranty of equipment or materials by the Agricultural Experiment Station of the University of Puerto Rico, nor is this mention a statement of preference.
} 
J. Agric. Univ. P.R. VOL. 77, NO. 3-4, JULY/OCTOBER, 1993117

by the FMC Company, was selected (11). This general approach has been taken by several research groups, and our work was done under the suggested framework.

Previous works on sorption isotherms of fruits include the one by Iglesias and Chirife (9) They reported monolayer values for freeze-dried pineapple pulp by using the B.E.T. equation. Their results were: $\mathrm{W}_{m}=$ $19.5,10.8$, and $7.3 \mathrm{~g} / 100 \mathrm{~g}$ at 5,45 and $60^{\circ} \mathrm{C}$, respectively. Further studies on the accurate characterization of the pineapple pulp sorption isotherms in a wide range of water activities is needed because this product is becoming a key ingredient in formulated foods.

The objective of this study was to compare two-parameter models and the G.A.B. model to predict the moisture sorption isotherms of freeze-dried pineapple pulp at several temperatures $(5,25,30,35$ and $55^{\circ} \mathrm{C}$ ). This comparison will help in selecting the right model for each range of application.

\section{MATERIALS AND METHODS}

The study was conducted on freeze-dried pineapple pulp. The pulp was collected from fruit juice manufacturing after centrifugation. The pulp was frozen to $-5^{\circ} \mathrm{C}$ to reduce enzymatic activity and fermentation.

Slices of frozen pineapple, $1.0 \mathrm{~cm}$ thick, were dried in a Dura Stop Freeze Dryer (FTS Systems, Inc., New York, NY)4. The dried pulp was comminuted and the powdered product stored in plastic vessels with silica gel.

Sorption measurements were made at different water activity levels and temperatures. These levels were controlled by using preselected saturated salt solution in glass dessicators, according to Wolf et al. (20). The salts used were $\mathrm{LiCl} . \mathrm{H}_{2} 0, \mathrm{M}_{\mathrm{g}} \mathrm{Cl}_{6} 6 \mathrm{H}_{2} \mathrm{O}, \mathrm{K}_{2} \mathrm{CO}_{3}, \mathrm{NaBr} .2 \mathrm{H}_{2} 0, \mathrm{NaCl}$, $\mathrm{KCl}, \mathrm{K}_{2} \mathrm{Cr}_{4}$ and $\mathrm{K}_{2} \mathrm{SO}_{4}$ corresponding to the following water activities at $25^{\circ} \mathrm{C}: 0.11,0.32,0.43,0.58,0.75,0.85,0.87$, and 0.97 , respectively. Microcrystalline cellulose (Avicel PH-101, FMC, New York, NY) ${ }^{4}$ was the reference material for the determination of sorption isotherms because of its defined and stable sorption properties. In general, test runs were made at temperatures in the range of 5 to $55^{\circ} \mathrm{C}$. In order to determine the water content, we dried samples of 10 grams of the freeze-dried pineapple pulp in a vacuum oven, where the pressure was less than 100 $\mathrm{mm} \mathrm{Hg}$, at $70^{\circ} \mathrm{C}$ for 6 hours according to A.O.A.C., sections 22.013 and 22.014 (2). Moisture content was calculated from the weight of the dry sample and expressed as percentage of original sample.

In the case of the six two-parameter models, the equations were rearranged in a linear expression to relate the water activity and the equilibrium moisture content. The constants of each model are evaluated by a linear regression analysis. 
A quadratic regression was conducted on sorption data to obtain the $\alpha, \beta$, and $\gamma$ values for the G.A.B. model. The original parameters $\left(W_{m}\right.$, $\mathrm{k}$ and $\mathrm{C}$ ) were calculated after solving equations 6,7 , and 8 . Only the positive solution of the second degree equation was considered because of its physical meaning.

The quality of the fit was judged from the value of the percentage root mean square:

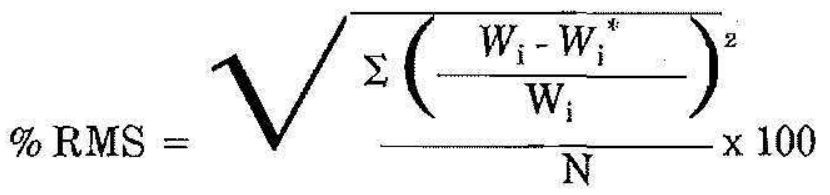

where $\mathrm{W}_{\mathrm{i}}$ is the experimental water content, $\mathrm{W}_{\mathrm{i}}{ }^{*}$ is the calculated water content, and $\mathrm{N}$ is the number of experimental points.

Each data point reported is the average for three replicates, and each test was conducted with a fresh sample. All measured values were considered and the mainframe version of SAS ${ }^{\text {TM }}$ was used to perform all statistical analyses.

The regression was performedd using the raw data, i.e., without averaging the three values measured at each water activity level.

\section{RESULTS AND DISCUSSION}

Figure 1 shows the equilibrium moisture content for freeze-dried pineapple pulp at different temperatures. The shape of the water sorption isotherms was similar to those reported for other freeze-dried fruits and food models. At water activity levels below 0.5, equilibrium moisture content remains under $20 \mathrm{~kg} \mathrm{H}_{2} 0 / 100 \mathrm{~kg}$ of dry solids; nevertheless, when water activity is over 0.5 , the equilibrium moisture content increases faster with small increments in water activity. The temperature effect in the sorption process is more evident at upper water activity levels. In general, as temperature is increased, equilibrium moisture content decreases. These results agree with sorption results reported for other fruits and food model systems (15), snack foods (12), papaya (6), banana (16) and plantain (1).

Figure 1 also shows that for water activity values higher than 0.8 there is a dramatic increase in moisture content; thus, it is difficult to describe the behavior of the product in the entire water activity range with a single model. The sorption data at $55^{\circ} \mathrm{C}$ was very low, and the typical sigmoid curve was not detected. The sorption values of microcrystalline cellulose at the selected water activity levels are shown in figure 2 ; results are very similar to those accepted as standards by COST 90 and reported by Jowitt et al. (11). 
J. Agric. Univ. P.R. vol. 77, NO. 3-4, JULY/OCTOBER, 1993119

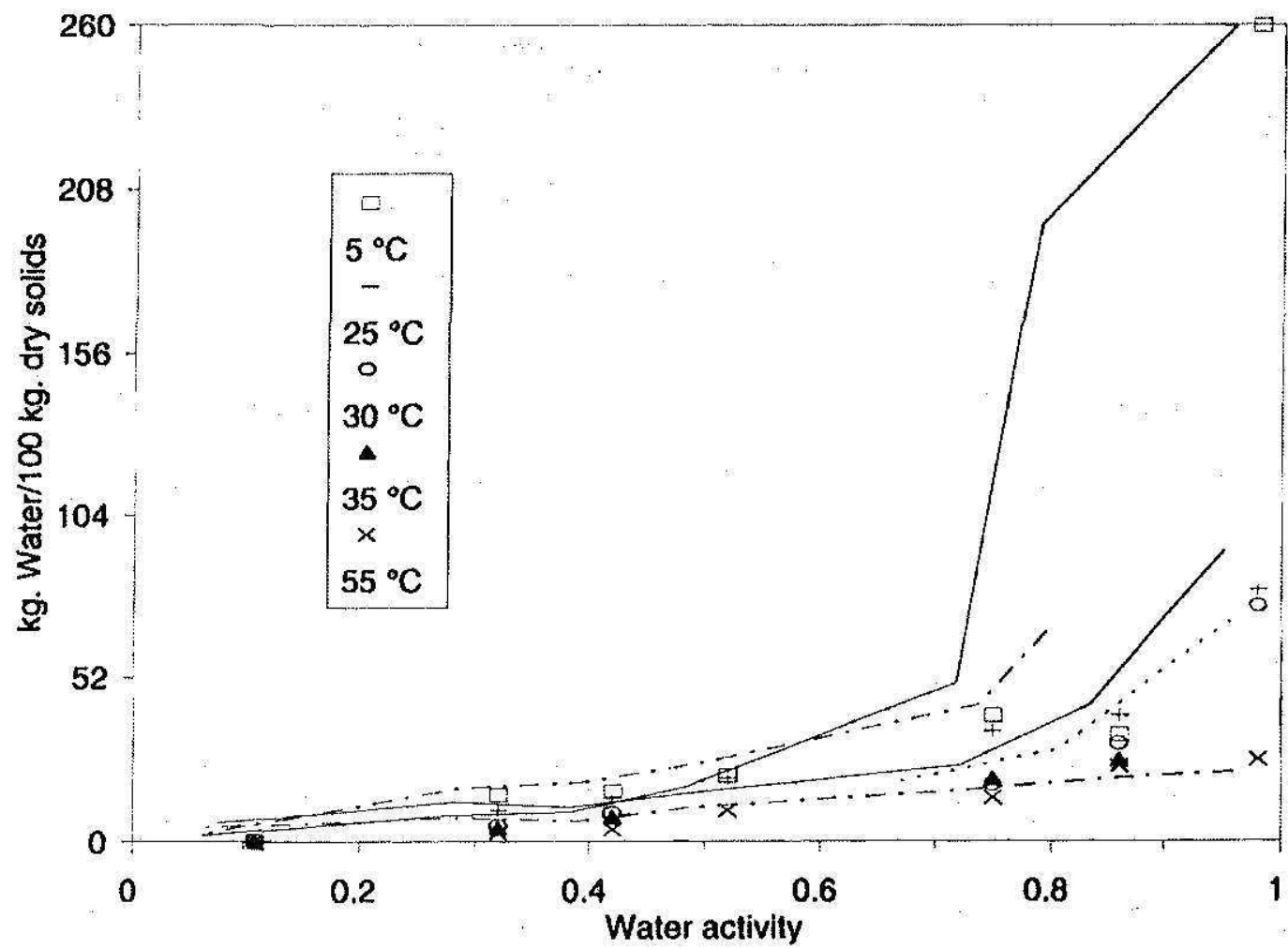

FIG. 1.-Sorption moisture isotherms for freeze-dried pineapple pulp at $5,25,30,35$ and $55^{\circ} \mathrm{C}$.

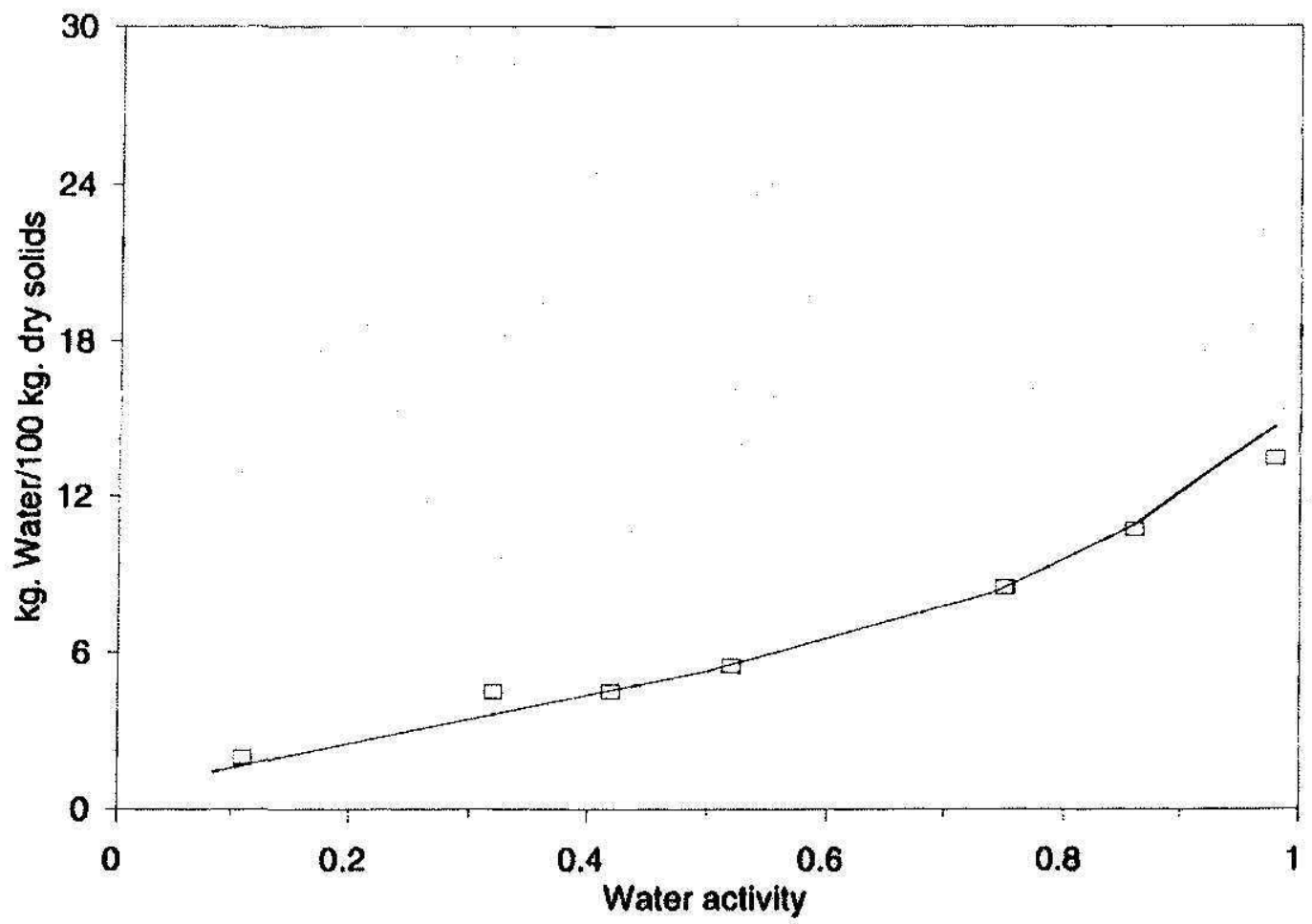

FiG. 2-Sorption moisture isotherm for microcrystalline cellulose at $26^{\circ} \mathrm{C}$. 
The sorption data of freeze-dried pineapple pulp was interpreted in terms of six two-parameter sorption models: Henderson (8), IglesiasChirife (10), Oswin (17), Chung-Pfost (5), Halsey (4) and Smith (3). A linear regression analysis for each model, using the experimental data in selected intervals, permits the evaluation of the fitting parameters of the equations. Table 2 shows the regression results for all six two-parameter models under consideration.

TABLE 2. Regression results for different sorption isotherm models applied to freeze-dried pineapple pulp

\begin{tabular}{|c|c|c|c|c|c|}
\hline \multirow[b]{2}{*}{ Sorption model } & \multicolumn{5}{|c|}{ Temperature $\left({ }^{\circ} \mathrm{C}\right)$} \\
\hline & 5 & 25 & 30 & 35 & 55 \\
\hline Iglesias and & & & & & \\
\hline \multicolumn{6}{|l|}{ Chirife } \\
\hline $\mathrm{C}_{1}(\mathrm{bp})$ & 3.37 & 3.82 & 3.19 & 3.23 & 3.26 \\
\hline $\mathrm{C}_{2}(\mathrm{p})$ & 1.42 & 1.08 & 1.48 & 1.43 & 1.06 \\
\hline$r^{2}$ & 0.99 & 0.95 & 0.97 & 0.95 & 0.97 \\
\hline Std. error & 0.06 & 0.18 & 0.09 & 0.16 & 0.12 \\
\hline \multicolumn{6}{|l|}{ Henderson } \\
\hline$C_{1}\left({ }^{*} 10^{-4}\right)$ & 3.88 & 3.94 & 2.43 & 2.57 & 3.72 \\
\hline $\mathrm{n}$ & 0.67 & 0.77 & 0.92 & 0.91 & 0.98 \\
\hline$r^{2}$ & 0.96 & 0.96 & 0.99 & 0.98 & 0.96 \\
\hline Std, error & 0.20 & 0.18 & 0.09 & 0.13 & 0.21 \\
\hline & & & & & \\
\hline Oswin & & 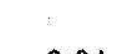 & & & $\cap 0$ \\
\hline $\mathrm{C}_{1}$ & 16.89 & 9.04 & 11.85 & 13.06 & 9.26 \\
\hline$n$ & 1.22 & 0.95 & 0.91 & 1.00 & 1.17 \\
\hline$r^{2}$ & 0.99 & 0.91 & 0.99 & 0.99 & 0.99 \\
\hline Std. error & 0.10 & 0.26 & 0.07 & 0.04 & 0.06 \\
\hline \multicolumn{6}{|l|}{ Chung-Pfost } \\
\hline$C_{1}\left(* 10^{-2}\right)$ & -1.91 & -27.70 & -8.11 & -8.79 & -13.95 \\
\hline $\mathrm{C}_{2}\left(^{*} 10^{-3}\right)$ & 3.00 & 2.30 & 1.70 & 1.60 & 1.40 \\
\hline$r^{2}$ & 0.78 & 0.98 & 0.96 & 0.96 & 0.96 \\
\hline Std. error & 38.62 & 0.13 & 2.24 & 2.26 & 1.29 \\
\hline \multicolumn{6}{|l|}{ Halsey } \\
\hline $\mathrm{C}_{1}$ & 1.07 & 0.99 & 1.35 & 1.27 & 0.72 \\
\hline$n$ & -0.55 & -0.63 & -0.76 & -0.74 & -0.53 \\
\hline$x^{2}$ & 0.93 & 0.96 & 0.98 & 0.92 & 0.98 \\
\hline Std. error & 0.18 & 0.12 & 0.16 & 0.20 & 0.14 \\
\hline \multicolumn{6}{|l|}{ Smith } \\
\hline $\mathrm{C}_{1}(* 10)$ & -7.13 & -1.03 & -0.88 & -1.35 & 0.62 \\
\hline$C_{2}(* 10)$ & -8.27 & -2.62 & -2.27 & -2.46 & -0.55 \\
\hline$r^{2}$ & 0.87 & 0.93 & 0.97 & 0.95 & 0.86 \\
\hline Std, error & 34.83 & 6.68 & 3.43 & 4.75 & 2.36 \\
\hline
\end{tabular}


Figures 3, 5, 7, 9 and 11 show the representation of sorption data using the Henderson, Iglesias-Chirife, and Halsey models. The Henderson equation, as well as the Iglesias-Chirife equation, fits the experimental data well. The constants corresponding to the Henderson model are similar to the values reported for other similar fruits such as peaches and prunes (8). In terms of the Iglesias-Chirife equation, the " $b$ " and " $p$ " values are similar to those reported for whole pineapples. One of the nice features about these three models is that the two parameters in each of these models did not change much with temperature.

A good agreement was found between the experimental and the predicted data during the Oswin equation below 0.55 water activity level. The constant " $n$ " of the model is less sensitive to temperature than the constant "C." The Chung-Pfost model showed good predicting capabilities when applied to data between 25 and $55^{\circ} \mathrm{C}$. The constants of the Smith equation showed significant temperature dependency. Figures 4,6, 8, 10 and 12 show the plots for Oswin, Smith, and Chung-Pfost models.

In general, the six two-parameter models exhibited good predictibility capabilities in the following water activity ranges:

$\begin{array}{lll}\text { Halsey } & 0 & 0.75 \\ \text { Henderson } & 0 & 1.0 \\ \text { Iglesias-Chirife } & 0 & 0.85 \\ \text { Oswin } & 0 & 0.55 \\ \text { Smith } & 0.75 & 1.0 \\ \text { Chung-Pfost } & 0.5 & 1.0 \quad \text { (not acceptable at } 5^{\circ} \mathrm{C} \text { ) }\end{array}$

These ranges were identified by assessing the goodness of fit of the model in a given water activity interval. If the coefficient of determination was lower than 0.85 , the proposed interval was not acceptable, and a new one should be considered until exceeding this lower limit.

Table 3 presents the regression results for freeze-dried pineapple pulp and microcrystalline cellulose using the G.A.B. model. The C, K, $\mathrm{W}_{m}$ values obtained for microcrystalline cellulose are close to the COST standards $(11)\left(C=8.776, K=0.772\right.$, and $\left.\mathrm{W}_{\mathrm{m}}=4.064\right)$. In general, the results for pineapple pulp were acceptable because the data was spread among the entire range of water activities. In some cases, because extremely high or extremely low hygroscopicity (at $5^{\circ}$ and $55^{\circ} \mathrm{C}$, respectively), it was not possible to calculate the $\mathrm{C}, \mathrm{K}$, and $\mathrm{W}_{\mathrm{m}}$ values. This is not unexpected because the model was tested beyond the range of applicability, i.e., water activity higher than 0.9 and very low moisture contents. It is also important to mention that the monolayer values $\left(W_{m}\right)$ predicted by the G.A.B. model are similar to those predicted by IglesiasChirife (9) using the BET equation. Goodness of fit of the G.A.B. equation 


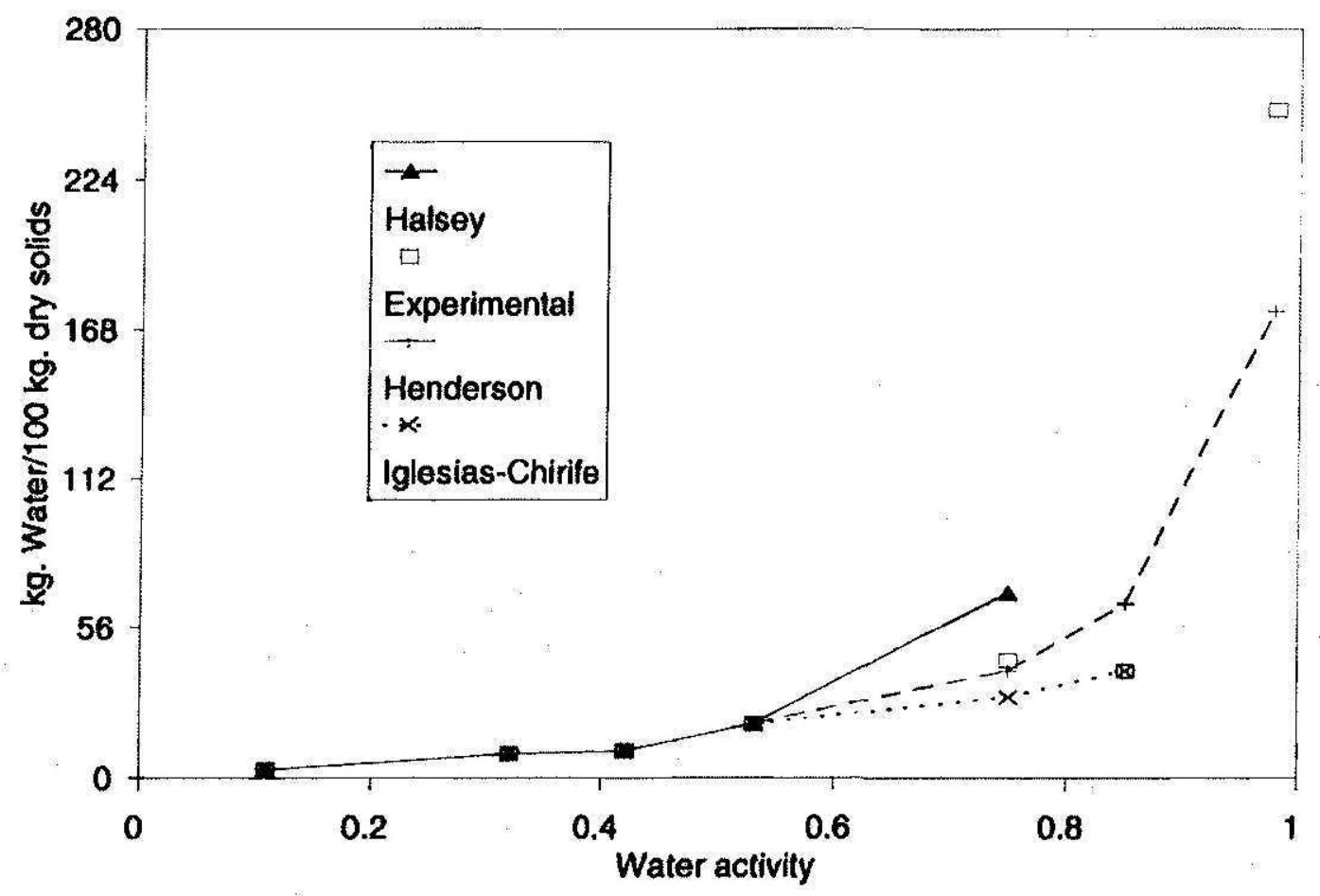

FIG. 3.-Isotherm representation by different sorption models at $5^{\circ} \mathrm{C}$.

in a wide range of conditions, and its physically meaningful coefficients make this model an attractive one to predict the sorption properties of a variety of food products, including the freeze-dried pineapple pulp.

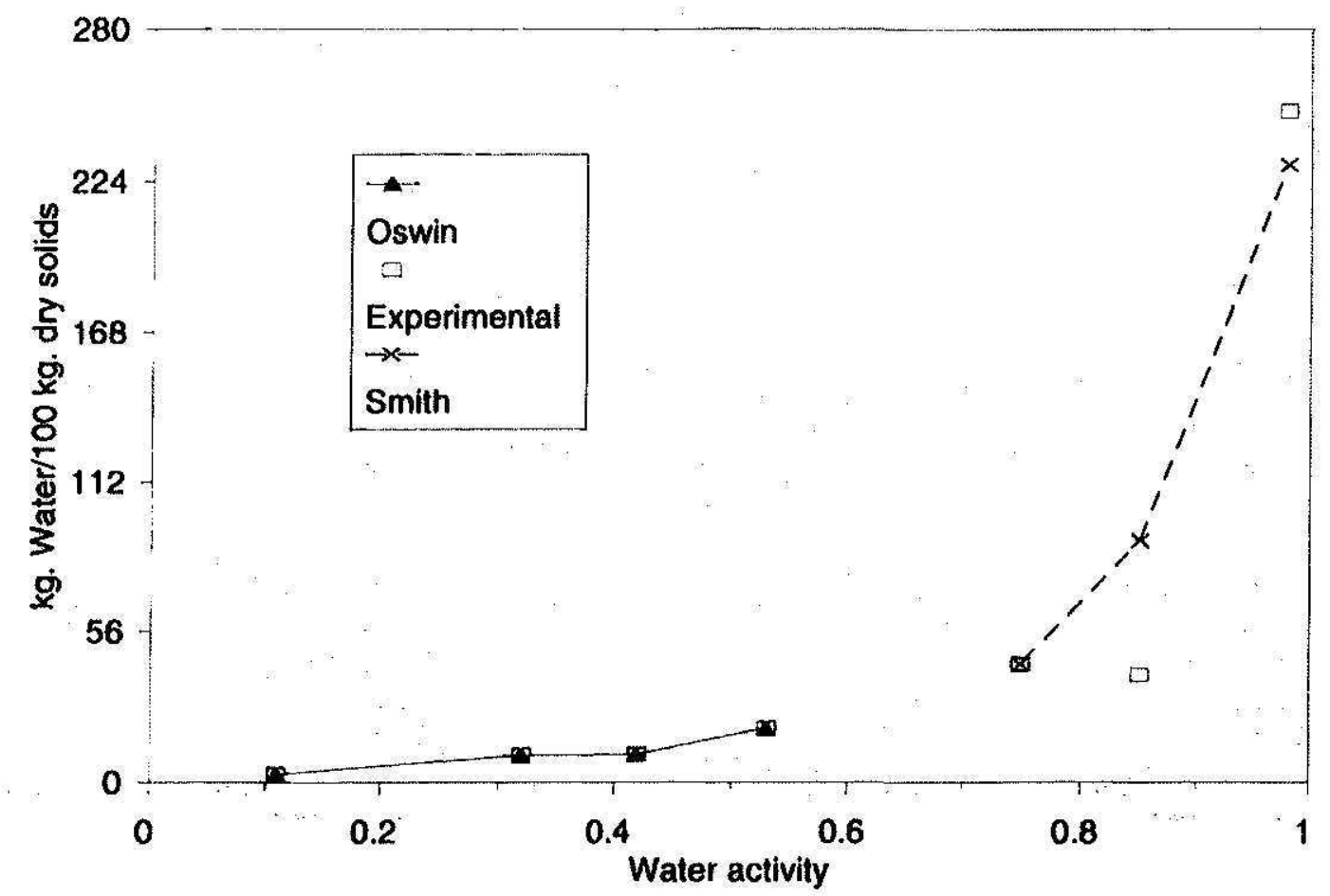

FIG. 4.-Isotherm representation by different sorption models at $5^{\circ} \mathrm{C}$. 
J. Agric. Univ. P.R. vol. 77, No. 3-4, JULY/OCTOBER, 1993123

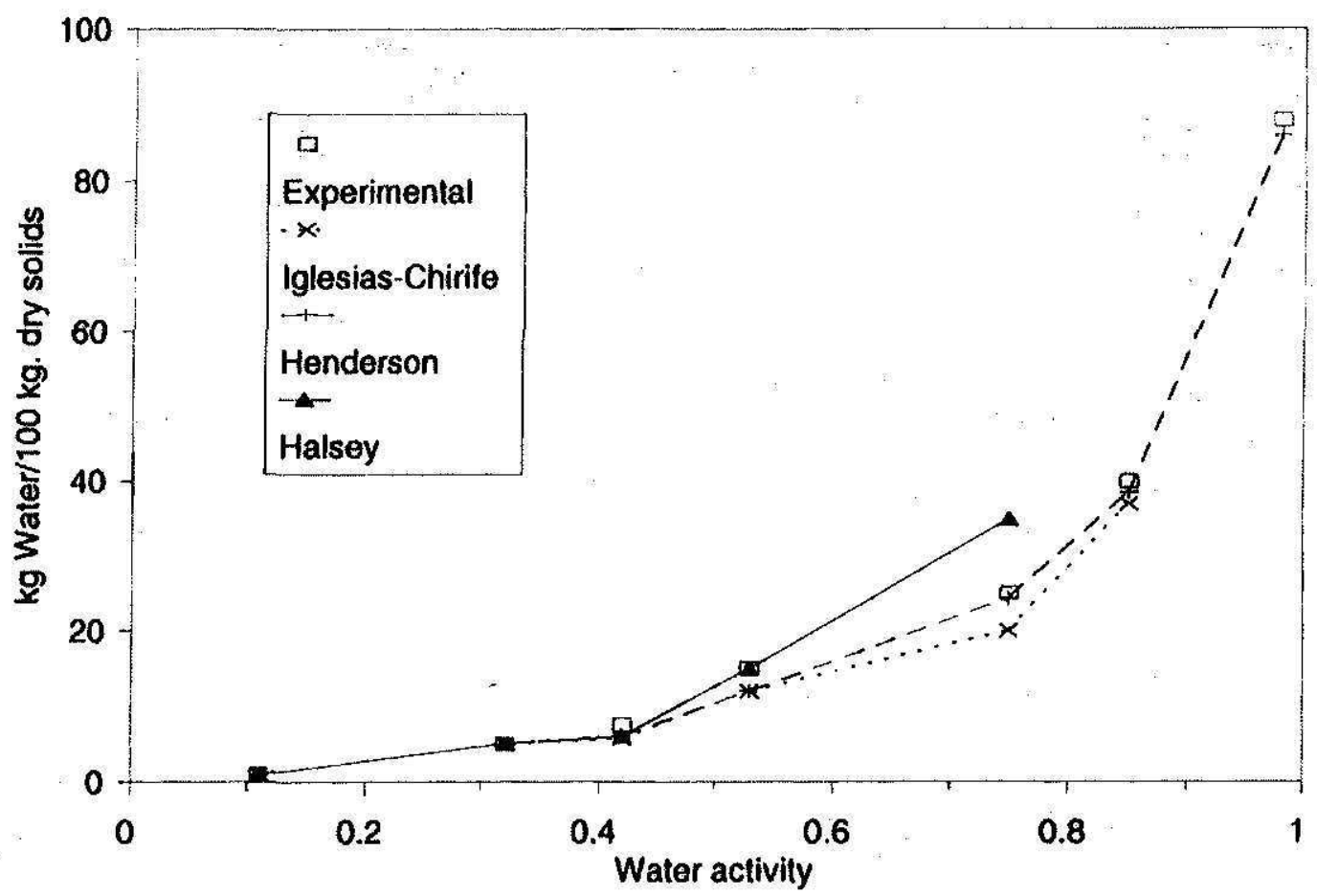

FrG. 5.-Isotherm representation by different sorption models at $25^{\circ} \mathrm{C}$.

In conclusion, sorption data of freeze-dried pineapple pulp may be predicted by all the models discussed in this study, provided they are used in the water activity and temperature ranges already indicated. On

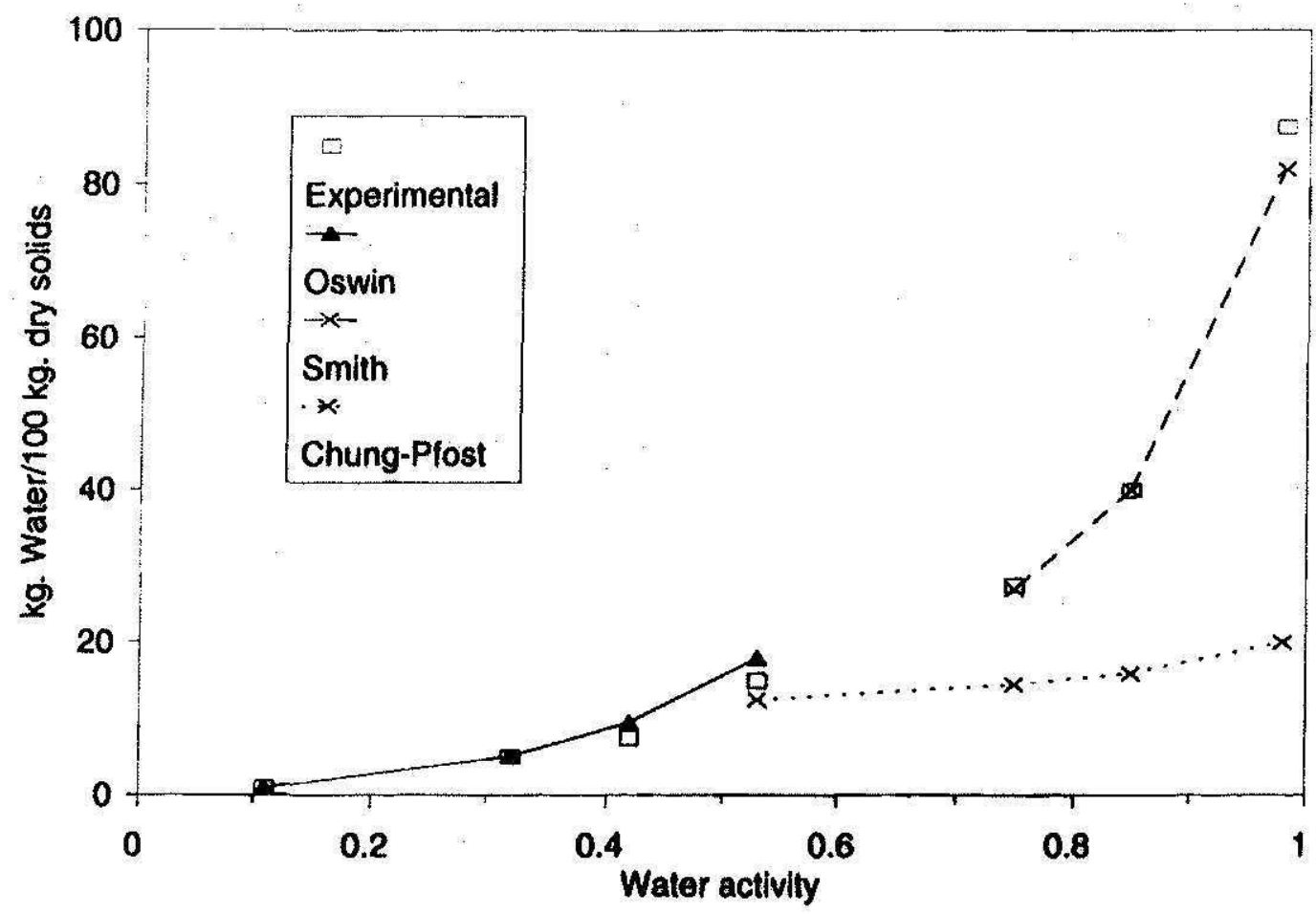

Fig. 6. -Isotherm representation by different sorption models at $25^{\circ} \mathrm{C}$. 


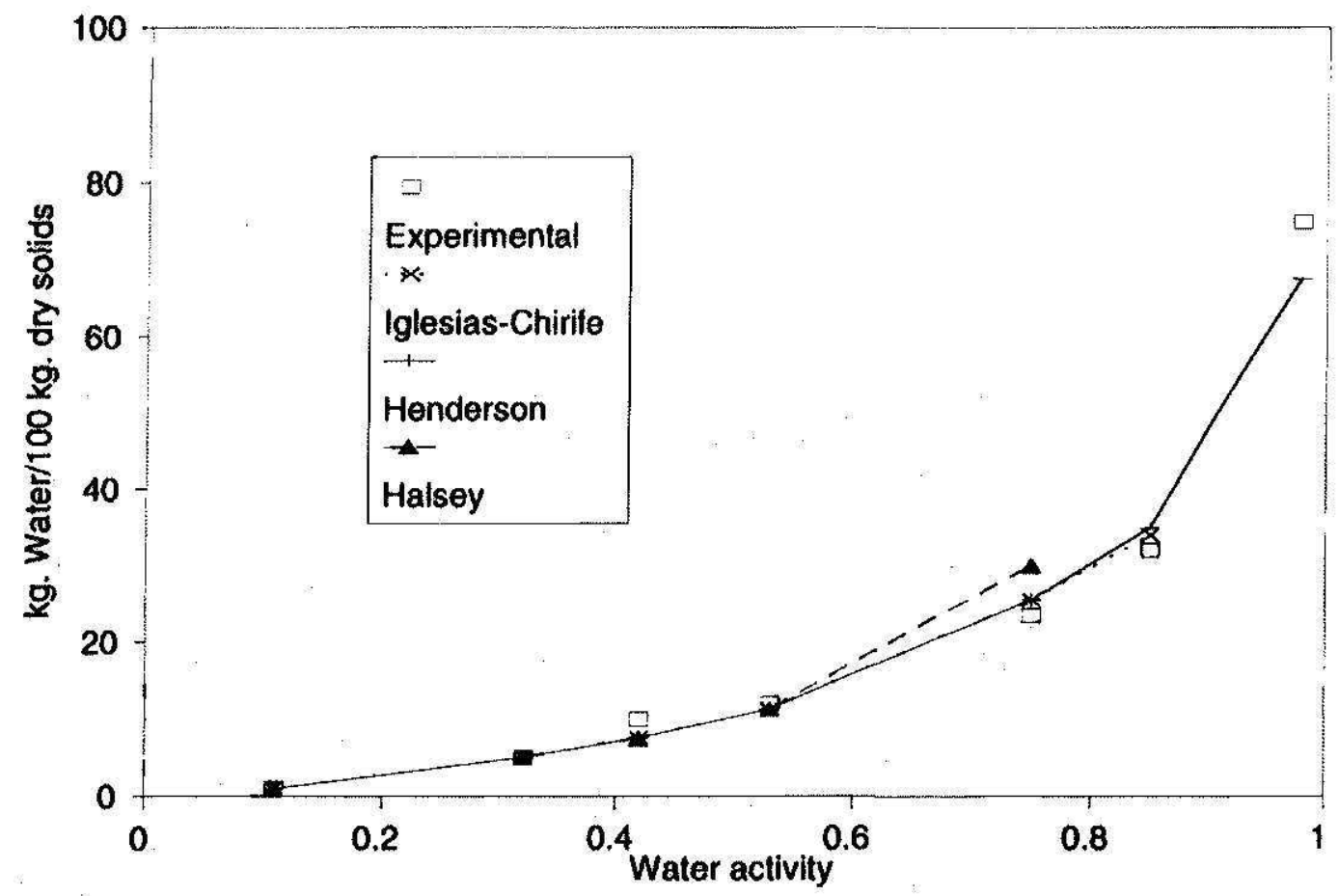

FiG. 7.-Isotherm representation by different sorption models at $30^{\circ} \mathrm{C}$.

the basis of the range of applicability, the slight variation of the constants with temperature, and the fact they have only two parameters, the most useful models were the ones proposed by Henderson (8) and Iglesias

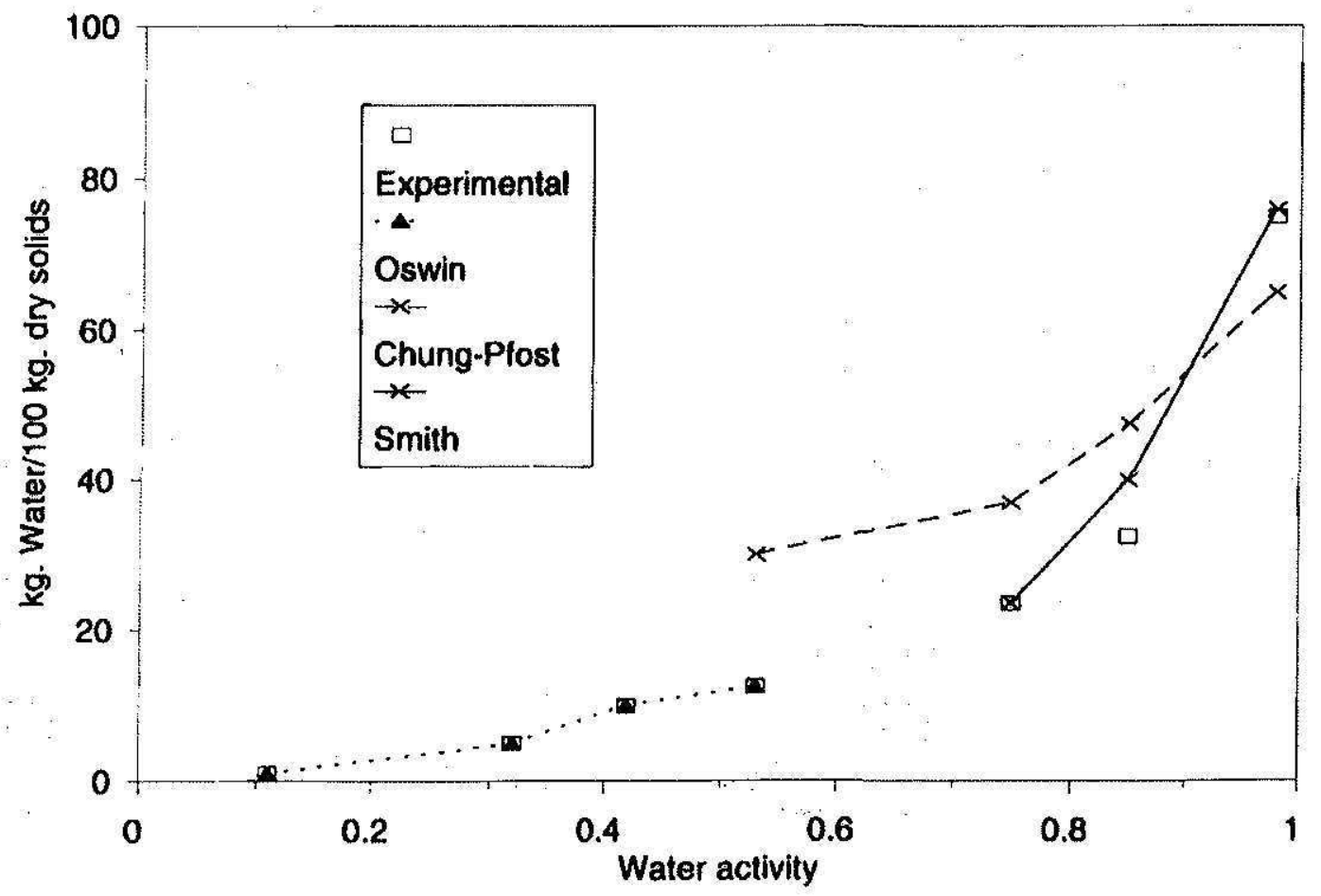

FiG. 8.-Isotherm representation by different sorption models at $30^{\circ} \mathrm{C}$. 
J. Agric. Univ. P.R. VOL. 77, NO. 3-4, JULY/OCTOBER, 1993125

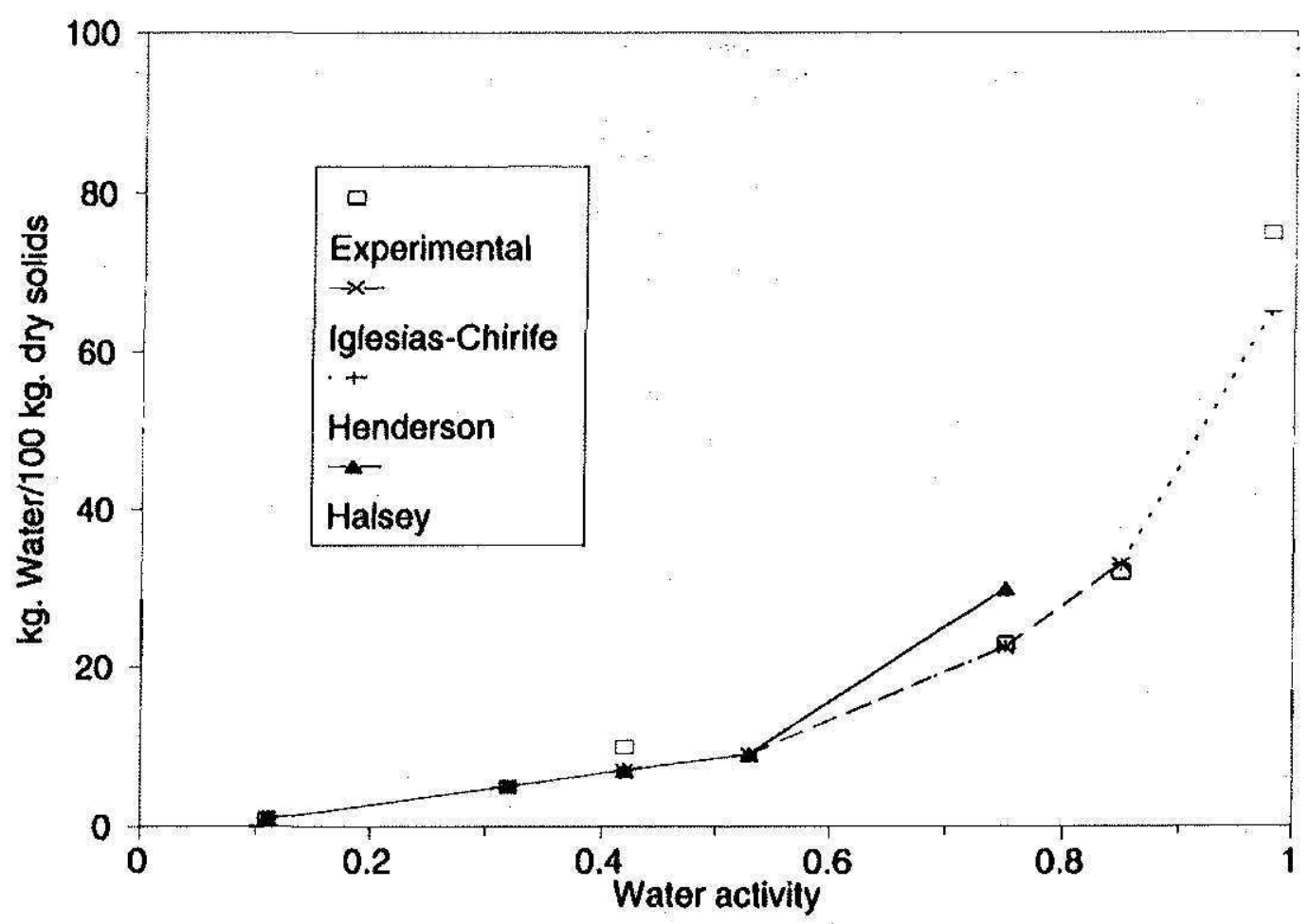

FiG. 9.-Isotherm representation by different sorption models at $35^{\circ} \mathrm{C}$.

-Chirife (10). All the correlation coefficients for these two models were above 0.95 . The G.A.B. model could be useful also, but it has more parameters and is more elaborate to estimate.

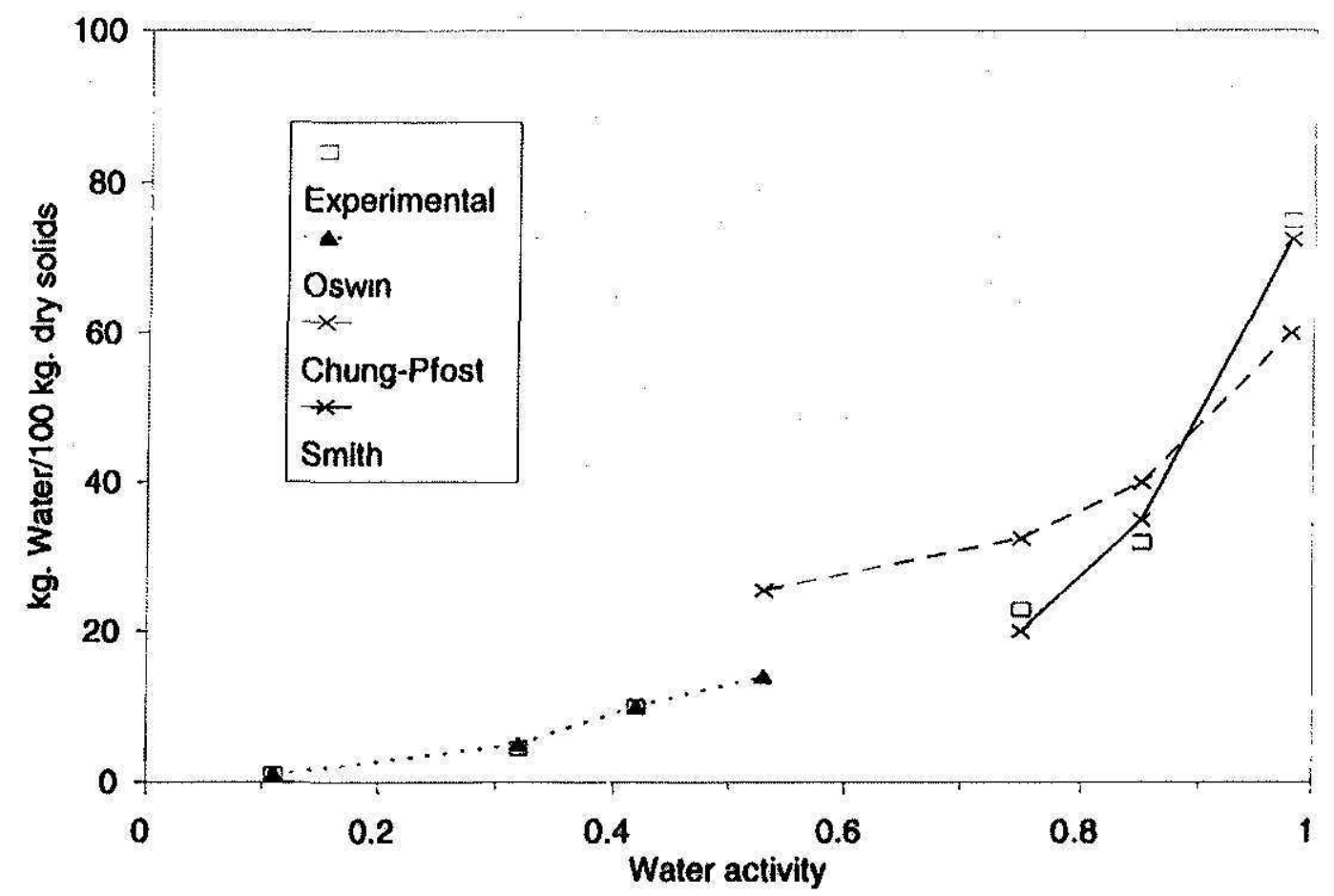

Fra. 10.-Isotherm representation by different sorption models at $35^{\circ} \mathrm{C}$. 


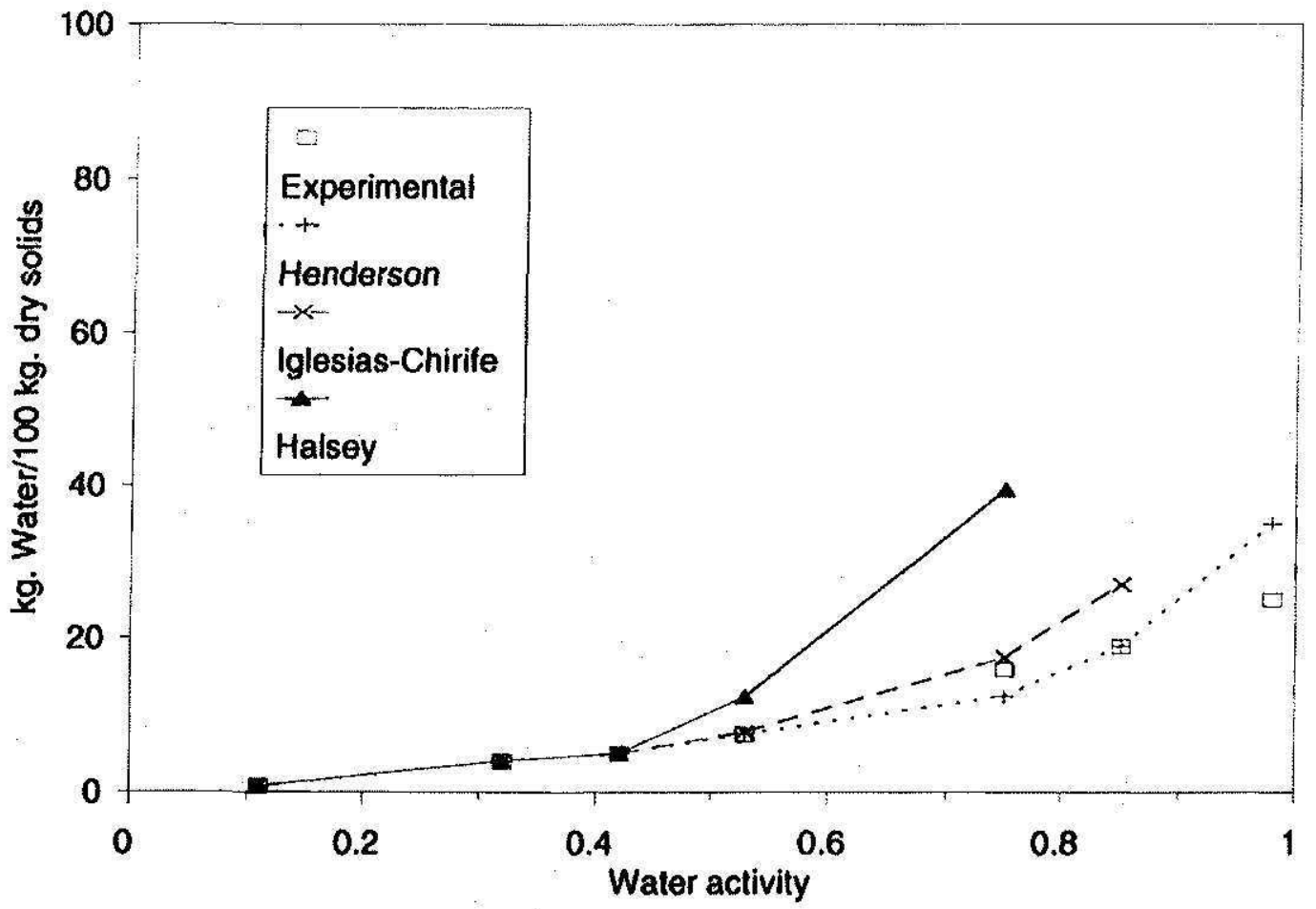

Fig. 11,-Isotherm representation by different sorption models at $55^{\circ} \mathrm{C}$.

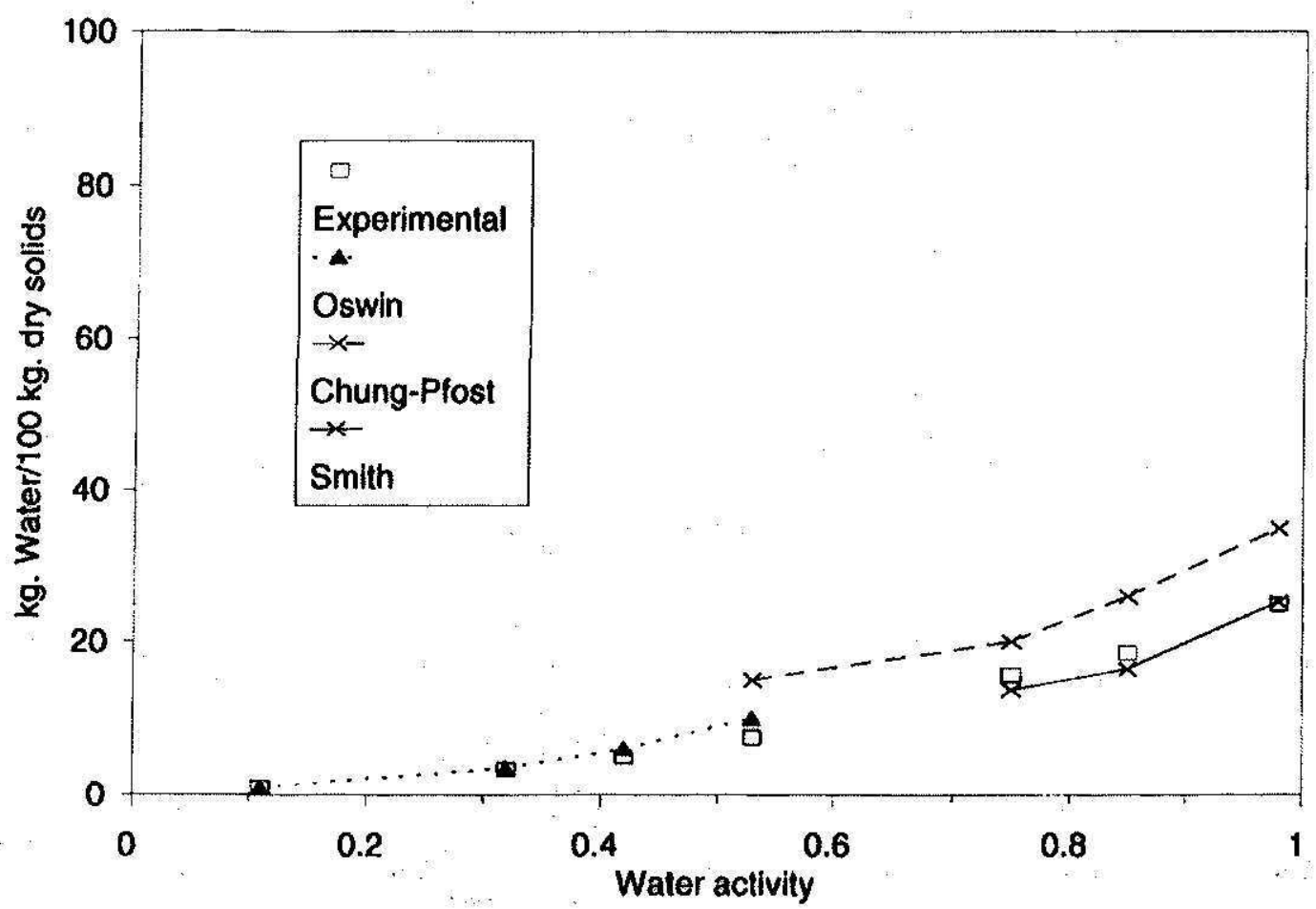

Fig. 12.-Isotherm representation by different sorption models at $55^{\circ} \mathrm{C}$. 


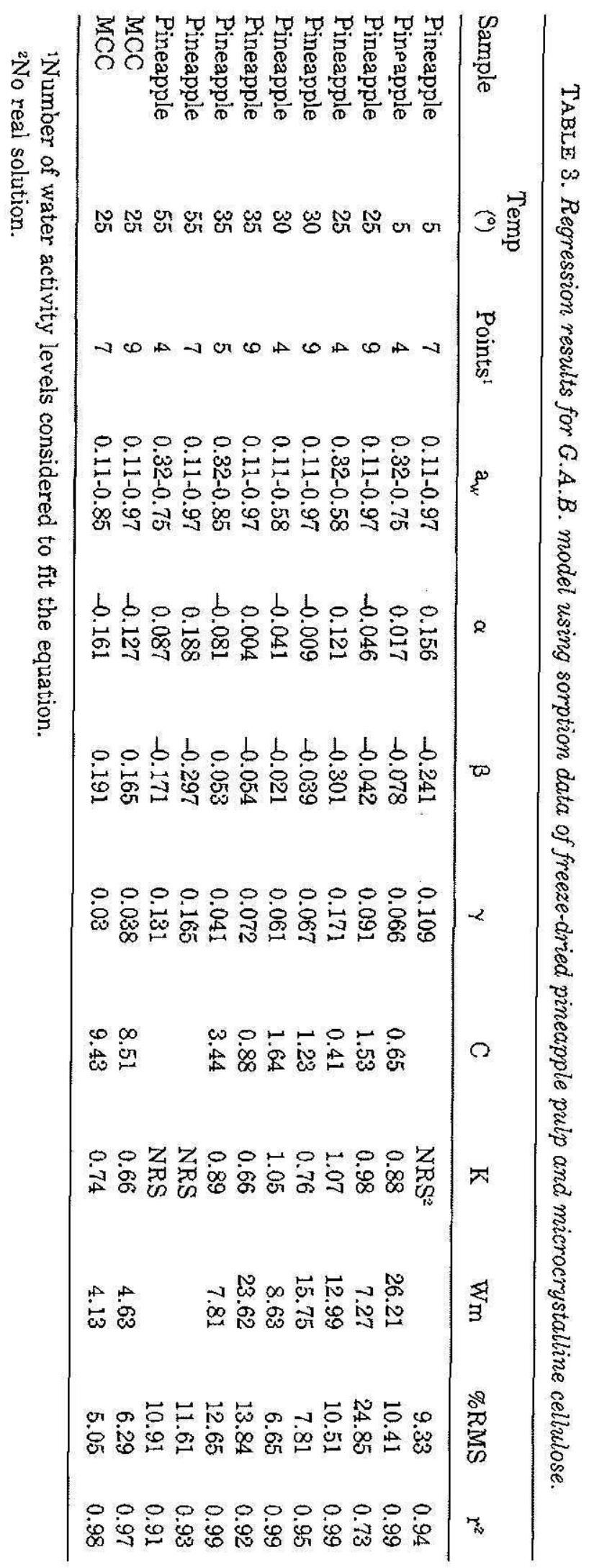

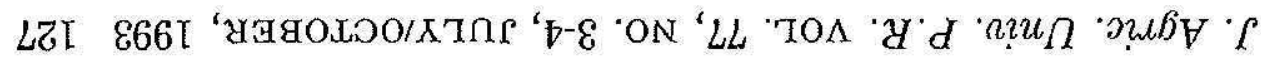




\section{LITERATURE CITED}

1. Ajibola, O. O., 1986. Desorption isotherms for plantain at several temperatures. $J$. Food Sci. 51:169-71.

2. A.O.A.C., 1984. Official Methods of Analysis of the Association of Official Analytical Chemists. 14th edition. Association of Official Analytical Chemists, Inc. Arlington, Virginia.

3. Boquet, R., J., Chirife and H. A. Iglesias, 1980. Technical note: On the equivalence of isotherm equations. J. Food Technol. 15:345-49.

4. Chirife, J. and H. Iglesias, 1978. Equations for fitting water sorption isotherms of foods. Part 1 - a review. J. Food Technol. 13:159-74.

5. Chung, D. S. and H. B. Pfost, 1967. Adsorption and desorption of water vapor by cereal grains and their products. II. Development of the general isotherm equation. Trans. ASAE 10:552-55.

6. De Gois, V. A. and J. Cal-Vidal, 1986. Water sorption characteristics of freeze dried papaya in powdered and granular forms. Can. Inst. Food Sci. Technol. J. 19(1):7-11.

7. DeMan, J. M., 1982. Principles of Food Chemistry. The AVI Publishing Company, Inc. Westport, Conn.

8. Henderson, S. M., 1952. A basic concept of equilibrium moisture. Agric. Eng. 33:2932.

9. Iglesias, H. A. and J. Chirife, 1976. B.E.T. monolayer values in dehidrated foods and food components. Lebensm-Wiss. U. - Technol. 9, 107-113.

10. — and - 1978. An empirical equation for fitting water sorption isotherms of fruits and related products. Can. Inst. Food Sci. Technol. J. 11:12-15.

11. Jowitt, R., F. Escher, B. Hallstrom, H. F. Th. Meffert, W. Spiess and G. Vos, 1983. Physical Properties of Foods. Applied Seience Publishers. London.

12. Katz, E. E. and T. P. Labuza, 1981. Effect of water activity on the sensory crispness and mechanical deformation of snack food products. J. Food Sci. 46, 403-409.

13. Kapsalis, J., 1987. Influences of hysteresis and temperature on moisture sorption isotherms. In: Water Activity: Theory and Application to Food. L. B. Rockland and L. K. Beuchat (Eds.). Marcel Decker, New York, NY.

14. Labuza, T. P., 1968. Sorption phenomena in foods. Food Technol. 22:15-24.

15. Lee, S. H. and T. P. Labuza, 1975. Destruction of ascorbic acid as a function of water activity. J. Food Sci. 40:370-73.

16. Lima, A. W. O. and J. Cal-Vidal, 1983. Hygroscopic behaviour of freeze dried bananas. J. Food Technol, 18:687-96.

17. Rizvi, S. S. H. and A. L. Benado, 1984. Thermodynamic properties of dehydrated foods. Food Technol. 51(3):83-92.

18. Saravacos, G. D., 1967. Effect of the drying method on the water sorption of dehydrated apple and potato. J. Food Sci. 32:81.

19. and R. M. Stinchfield, 1965. Effect of temperature and pressure on the sorption of water vapor by freeze dried food materials. J. Food Sci. 30:779-86.

20. Wolf, W. W. Spiess, W. Jung, H. Weisser, H. Bizot and R. B. Duckworth, 1984. The water vapour sorption isotherms of microcrystalline cellulose (MCC) and of purified potato starch. Results of a collaborative study. J.Food. Eng. 3:51-73. 